\title{
Strategi Bertahan Hidup Rumah Tangga Miskin dengan Kepala Rumah Tangga Perempuan
}

\author{
HASTUTI \\ Jurusan Pendidikan Geografi FIS UNY \\ email : hastuti@uny.ac.id
}

\begin{abstract}
Abstrak
Penelitian ini bertujuan mengkaji profil rumah tangga dan strategi bertahan hidup rumah tangga miskin. Subjek penelitian adalah rumah tangga dengan kepala rumah tangga perempuan di Desa Donokerto, Turi, Sleman, DIY. Analisis data dilakukan dengan memilah dan memilih fenomena di lapangan sesuai dengan fokus penelitian melalui pengamatan, pemahaman, dan interpretasi. Hasil penelitian menunjukkan bahwa rumah tangga dengan kepala rumah tangga perempuan kesulitan memenuhi kebutuhan ekonomi ketika dihadapkan dengan ketiadaan sumberdaya produktif. Upaya dalam mengatasi kesulitan ekonomi melalui pemanfaatan sumberdaya yang tersedia di sekitarnya dan melibatkan seluruh anggota rumah tangga agar memiliki kegiatan yang dapat menghasilkan pendapatan, meminjam uang kepada tetangga maupun dari keluarga terdekat, berhutang kebutuhan di warung-warung terdekat untuk pemenuhan kebutuhan, menekan kebutuhan rumah tangga serendah mungkin meskipun dengan kualitas pemenuhan kebutuhan yang minimal seperti kebutuhan pangan, menjadikan rentan terhadap gangguan kesehatan.
\end{abstract}

Kata Kunci : Strategi Bertahan Hidup, Rumah Tangga Miskin, KRTP

\begin{abstract}
This research aims to study the profile of households and survival strategies of poor households. The research subjects include households with female heads in the village of Donokerto, Turi, Sleman, Yogyakarta. Data analysis was performed by sorting and selecting the phenomenon in the field related to the focus of research through observations, understandings, and interpretations. The findings show that households with female heads find difficulties in fulfilling the economic needs when they are faced with a lack of productive resources. The efforts to overcome economic difficulties include utilizing available resources in the surroundings and involving all members of the household in order to have activities that can generate income, borrowing money from neighbors and relatives, borrowing goods to fulfill needs from the closest stalls, pressing needs of the household as low as possible despite the minimum quality fulfillment such as food needs that make susceptible to health problems.
\end{abstract}

Keywords: Survival Strategies, Poor household, KRTP 


\section{PENDAHULUAN}

Perempuan dengan laki-laki dalam berumah tangga secara langsung peran kepala rumah tangga diberikan kepada laki-laki dengan tugas sebagai pencari nafkah utama. Perempuan sebagai istri memiliki tugas utama untuk mengelola rumah tangga. Status sosial perempuan dapat mengalami pergeseran dari status istri menjadi kepala rumah tangga apabila suami meninggal atau terjadi peristiwa perceraian (Sajogyo, 1991). Seringkali perempuan terpaksa menjadi kepala rumah tangga ketika suami meninggal atau sebab lain, sementara sejak awal perempuan tak dipersiapkan untuk menjadi kepala rumah tangga. Kepala rumah tangga merupakan pencari nafkah utama telah melekat dalam sebuah perkawinan tanpa melalui musyawarah, status tersebut tetap diemban suami tanpa memperhatikan apakah suami memiliki sumber pendapatan maupun dalam keadaan tak memiliki sumber pendapatan.

Diskriminasi terhadap perempuaan terus terjadi tak terkecuali dalam kegiatan ekono$\mathrm{mi}$, sebagai contoh pekerjaan yang sama boleh jadi perempuan diberi pekerjaan dengan upah sangat murah bahkan tidak mendapat upah sama sekali dari pekerjaan tersebut. Perempuan dianggap memiliki produktivitas rendah, rendahnya produktivitas perempuan dicerminkan oleh pendapatan yang diterima, karena perempuan dianggap memiliki $h u-$ man capital berupa pendidikan, latihan, dan pengalaman kerja yang lebih rendah.

Selama ini perempuan perdesaan melakukan kegiatan ekonomi sebagaimana dilakukan laki-laki, meskipun demikian perempuan tetap menderita akibat kebijakan pembangunan cenderung bias gender. Suratiyah dan Hariadi (1991) menyebutkan pengaruh teknologi pertanian terhadap perempuan tak hanya menghilangkan kesempatan kerja perempuan di pertanian tetapi juga kesempatan di luar pertanian. Pekerjaan di luar pertanian sulit dijangkau perempuan dengan pendidikan rendah.

Strategi bertahan hidup oleh masyarakat sebagian besar berkaitan dengan aspek ekonomi rumah tangga untuk memenuhi kebutuhan dasar sebagai upaya untuk bertahan hidup. Strategi bertahan hidup oleh masyarakat dilakukan dengan menambah pemasukan dan memperkecil pengeluaran. Perempuan harus bekerja untuk memperoleh pendapatan sebagai strategi memperoleh pemasukan untuk rumahtangganya. Disisi lain perempuan dihadapkan pada strategi untuk menekan pengeluaran rumah tangga. Langkah yang diambil perempuan adalah memilih pekerjaan yang mudah dijangkau dan biaya transportasi terjangkau bahkan kalaupun ada pekerjaan yang dapat dilakukan tanpa memerlukan biaya transportasi untuk menuju tempat bekerja. Berbagai kendala masih harus dihadapi perempuan yang bekerja, untuk akses dan kontrol terhadap sumberdaya merupakan kendala perempuan dalam memperoleh pendapatan. Rendahnya sumberdaya yang dimiliki perempuan de-ngan karakter pendidikan, modal, dan pengalaman yang terbatas menjadi kendala bagi perempuan untuk memasuki lapangan kerja.

Perempuan secara tidak sadar menerima takdir berpijak di dua tempat apabila menentukan pilihan terjun di sektor publik mereka harus tetap melakukan perannya di sektor domestik sehingga peran ganda harus dipikul oleh perempuan, sementara lakilaki dapat melepaskan tugas rumah tangga. Istilah peran ganda tersebut mulai mengalami pergeseran seiring dengan semakin banyaknya perempuan yang bekerja di sektor publik. Adanya peningkatan partisipasi perempuan menikah yang terlibat dalam pekerjaan guna memperoleh upah sehingga terjadi perubahan pembagian kerja antara laki laki dan perempuan dalam pekerjaan rumah tangga bahkan terjadi penurunan jam kerja perempuan dalam rumah tangga. Di dalam kondisi perempuan harus bekerja dapat dilihat dari dua sisi yaitu peran produksi dan reproduksi yang berpijak di rumah tangga dan di pasar kerja (Stichter, 1991). Istri harus melakukan upaya-upaya dengan bekerja apa saja agar mampu memenuhi kebutuhan apabila harus hidup tanpa suami sebagai pencari nafkah utama. Beban dan tanggung jawab suami harus diambil alih perempuan sehingga perempuan sebagai kepala rumah 
tangga akan memiliki beban ganda yang lebih berat. Sajogyo (1986), dibandingkan laki-laki bahwa perempuan perdesaan yang bekerja mengalami beberapa tekanan oleh pekerjaan rumah tangga dalam melakukan peran ganda, status perempuan sebagai istri, perbedaan penilaian dalam dua ranah pekerjaan yang dilakukan oleh perempuan, dan kesulitan mencari pengganti guna menyelesaikan berbagai pekerjaan mengurus rumah tangga. Fokus penelitian adalah profil rumah tangga dengan kepala rumah tangga perempuan dan strategi yang dilakukan perempuan kepala rumah tangga untuk mempertahankan kelangsungan hidup rumah tangganya.

\section{METODE}

Penelitian ini dilakukan di Desa Donokerto, Kecamatan Turi, Kabupaten Sleman, DIY, berawal dari keinginan untuk mengungkapkan secara mendalam tentang rumah tangga miskin dengan kepala rumah tangga perempuan. Data yang diperoleh melalui wawancara mendalam kemudian disusun dalam transkrip dengan difokuskan untuk menangkap makna kehidupan, pengalaman, kenyataan, maupun sisi kehidupan yang tersembunyi dan menganalisa berkaitan dengan strategi bertahan hidup rumah tangga dengan kepala rumah tangga perempuan. Huberman dan Miles (1992) dikuatkan (Bungin 2003) mengemukakan, bahwa analisis data dalam penelitian kualitatif meliputi reduksi data, kategorisasi, penyajian data dan verifikasi. Reduksi data dilakukan mulai dari proses pemilihan, penyederhanaan hingga transformasi data yang selanjutnya dilakukan verifikasi. Verifikasi dilakukan untuk mencapai kredibilitas data, cara ini dilakukan antara lain dengan triangulasi. Triangulasi dilakukan untuk mencocokan kebenaran informasi yang diberikan informan atau untuk membatu peneliti untuk lebih memahami suatu fenomena di lapangan.

\section{HASIL DAN PEMBAHASAN}

Rumah Tangga Miskin dengan Perempuan sebagai Kepala Rumah Tangga

Perempuan kepala rumah tangga miskin mencari nafkah dengan bekerja apa saja agar dapat memperoleh pendapatan disamping menyelesaikan tugas utama dalam bertanggungjawab terhadap pekerjaan rumah tangga. Perempuan kepala rumah tangga miskin menggunakan waktu dan tenaga untuk bekerja di luar rumah, bekerja di pertanian, dan peternakan. Keterbatasan kesempatan kerja dihadapkan dengan kebutuhan hidup yang meningkat mengakibatkan kesulitan mencapai kesejahteraan dan memperoleh tambahan pendapatan. Kondisi ini menjadi tantangan berat bagi perempuan kepala rumah tangga miskin dalam memperoleh sumber pendapatan.

Pendidikan merupakan salah satu cara meningkatkan kualitas sumberdaya manusia. Pendidikan yang memadai menjadikan seseorang mampu menganalisis setiap informasi secara kritis dan menciptakan iklim berpikir yang kreatif dan inovatif. Kemampuan berpikir membuat manusia dapat memanfaatkan setiap kesempatan yang tersedia dalam rangka untuk mewujudkan kesejahteraan hidupnya. Kemampuan berpikir dapat membuka kesempatan lebih luas kepada manusia termasuk untuk mengelola sumberdaya secara arif, berdaya guna, dan berkelanjutan sehingga bermanfaat bagi kehidupan masa kini dan masa depan. Sampai saat ini masih diyakini bahwa pendidikan menjadi faktor penting untuk meningkatkan sumberdaya manusia agar lebih arif dan bijaksana dalam menyikapi persoalan hidup. Melalui peningkatan pendidikan diharapkan perempuan kepala rumah tangga miskin memiliki kemampuan meningkatkan kualitas dirinya untuk mengambil keputusan dan melepaskan diri dari belenggu kemiskinan. Pendidikan perempuan kepala rumah tangga miskin relatif rendah. Perempuan akan dikalahkan untuk memperoleh prioritas pendidikan dalam situasi kemiskinan. Rendahnya pendidikan perempuan kepala rumah tangga menjadi kendala untuk memperoleh sumber pendapatan memadai ditambah dengan konstruksi sosial yang berlaku di daerah penelitian menempatkan perempuan bukan sebagai pencari nafkah utama.

Lahan merupakan modal penting di 
perdesaan yang masih menggantungkan pendapatannya dengan kegiatan usahatani. Penguasaan lahan merupakan variabel yang menentukan pendapatan rumah tangga dengan penguasaan lahan yang luas berarti pendapatan pertanian menjadi lebih banyak. Pemanfaatan pendapatan rumah tangga ditentukan oleh jumlah anggota rumah tangga yang menjadi tanggungan. Kesejahteraan dan keadaan sosial ekonomi rumah tangga ditentukan oleh jumlah anggota rumah tangga yang harus ditanggung. Rumah tangga dengan pendapatan sama, apabila jumlah tanggungan lebih sedikit, tentu saja akan lebih sejahtera dibandingkan dengan rumah tangga yang sama tetapi jumlah tanggungannya lebih besar. Jumlah tanggungan yang harus dipikul di rumah tangga dapat mencerminkan seberapa besar alokasi pendapatan rumah tangga untuk memenuhi konsumsi sampai pemenuhan kebutuhan untuk peningkatan kualitas sumberdaya manusia. Jumlah tanggungan mencerminkan seberapa besar pendapatan rumah tangga dimanfaatkan untuk memenuhi kebutuhan seluruh anggota rumah tangga yang menjadi tanggungannya, mulai dari pemenuhan kebutuhan pangan, pakaian, dan kebutuhan lain. Rumah tangga dengan pendapatan rendah, sebagian besar pendapatan bahkan seluruh pendapatan seringkali harus habis untuk pemenuhan konsumsi. Rumah tangga yang memiliki pendapatan kecil dengan beban tanggungan lebih banyak akan menghadapi kesulitan untuk meningkatkan kesejahteraan. Pendapatan yang kecil berarti hanya cukup untuk memenuhi kebutuhan konsumsi dan untuk meningkatkan kualitas hidup, seperti meningkatkan derajat, kesehatan, pendidikan, bahkan untuk investasi. Pemenuhan kebutuhan rumah tangga dihitung mulai dari pemenuhan kebutuhan pangan, sandang, dan kebutuhan lain yang diperlukan setiap anggota rumah tangga. Rumah tangga dengan pendapatan kecil, sebagian besar pendapatan bahkan seluruh pendapatan dimanfaatkan untuk pemenuhan kebutuhan pangan. Pos pengeluaran untuk pemenuhan kebutuhan pangan dapat mencapai separuh bahkan seluruh pendapatan rumah tangga.

Perempuan miskin harus menanggung beban lebih berat karena harus mencari nafkah dan melakukan tugas domestik. Perempuan sebagai kepala rumah tangga miskin di Desa Donokerto terpaksa sebagai pencari nafkah utama dengan keterbatasan pendidikan, kekurangan modal, memiliki keterbatasan ekonomi, keterbatasan dalam keterjangkauan terhadap fasilitas pelayanan kesehatan, modal, akses serta kontrol terhadap sumberdaya juga terbatas. Sepanjang hari seringkali perempuan kepala rumah tangga miskin harus menyelesaikan pekerjaan rumah tangga dan melakukan kegiatan ekonomi untuk memperoleh pendapatan.

Kesederhanaan tampak pada kehidupan sehari-hari perempuan kepala rumah tangga miskin tercermin dari pola makan, pakaian, dan tempat tinggal mereka. Perempuan kepala rumah tangga miskin setiap hari dapat makan nasi sehari tiga kali ketika masih memiliki persediaan beras apabila persediaan beras menipis perempuan kepala rumah tangga miskin memilih untuk makan masi sehari dua kali atau makan dengan bahan pokok ubi atau jagung sebagai alternatif makanan yang dapat dijangkau. Beras merupakan kebutuhan makan pokok yang harus dibeli ketika raskin yang diperoleh tidak mencukupi untuk memenuhi kebutuhan pangan mereka.

Waktu bekerja lebih panjang karena harus menyelesaikan pekerjaan rumah tangga dan mencari nafkah. Ketika pendapatan rumah tangga tidak dapat memenuhi kebutuhan rumah tangga, perempuan kepala rumah tangga harus melakukan berbagai upaya untuk mengatasi kesulitan ekonomi. Beban rumah tangga menjadi tanggung jawab perempuan kepala rumah tangga miskin sehingga mengandalkan kekuatan yang ada pada dirinya menjadi salah satu cara yang dapat dilakukan untuk mengatasi berbagai persoalan rumah tangga.

“......meskipun lelah karena harus mencari nafkah......saya harus tetap menyiapkan kebutuhan rumah tangga......memasak, mencuci, bersih-bersih rumah..." (Informan Ibu Suprih)

Gambaran kehidupan perempuan kepala 
rumah tangga miskin tampak dari kehidupan sehari- hari yang harus dilakukan Ibu Suprih. Ibu Suprih bertanggung jawab terhadap pemenuhan kebutuhan makan dan pakaian, harus mengasuh anak sendirian, dan mengatur tempat tinggal mulai dari bersih-bersih bahkan memperbaiki kerusakan yang dapat dilakukan sendiri. Perempuan kepala rumah tangga miskin melakukan seluruh pekerjaan rumah tangga dan bekerja secara rutin untuk memenuhi kebutuhan rumah tangga. Ibu Suprih masih harus menyelesaikan pekerjaaan rumah tangga dengan tidur lebih akhir dan bangun lebih awal untuk menyiapkan seluruh keperluan anggota rumah tangga. Setelah menyelesaikan pekerjaan rumah tangga Ibu Suprih bekerja mencari nafkah.

“....untuk memenuhi kebutuhan rumah tangga........saya harus bekerja......dengan mengolah lahan, menanam apa saja yang laku dijual...agar dapur mengepul....." (Informan Ibu Suprih)

Ibu Suprih bekerja dibantu anak-anaknya untuk mengelola lahan pertanian, memelihara ternak, kegiatan rutin menyelesaikan pekerjaan rumah tangga juga sering dibantu oleh anak perempuannya. Ibu Hardiyati bekerja di pertanian, peternakan dan memanfaatkan sumberdaya sekitar untuk memenuhi kebutuhan rumah tangga dan menyelesaikan pekerjaan rumah tangga.

“......setiap hari setelah memasak, mencuci piring, mencuci baju, bersih-bersih rumah.....saya kemudian menyiapkan diri pergi bekerja untuk memperoleh pendapatan....." (Informan Ibu Hardiyati)

Kondisi bangunan rumah Ibu Hardiyati meskipun sederhana telah berdinding tembok dengan lantai. Pada rumah tangga miskin dengan kepala rumah tangga perempuan karena keterbatasan ekonomi maka kondisi rumah sederhana. Ketika masuk ke rumah Ibu Hardiyati dapat dilihat perabotan rumah sangat sederhana. Di ruang depan terdapat sebuah almari kecil dan seperengkat meja kursi menerima tamu.

Pekerjaan rumah tangga dilakukan perempuan kepala rumah tangga dibantu ang- gota rumah tangga perempuan. Keputusan terkait pekerjaan rumah tangga banyak ditentukan perempuan kepala rumah tangga meskipun yang melakukan pekerjaan tersebut sering dibantu anggota rumah tangga yang lain. Perempuan kepala rumah tangga bertanggung jawab terhadap kelancaran di rumah tangga mulai dari membersihkan dan mencuci peralatan makan minum, mencuci, menyeterika, dan menyimpan pakaian, memasak dan menyiapkan makan minum, membersihkan tempat tidur, kamar, rumah dan lingkungan rumah, menyiapkan bahan bakar untuk rumah tangga.

“.....pekerjaan rumah tangga dianggap ringan dapat disambi- sambi mulai memanaskan air, menanak nasi, memasak sayur, cuci piring, gelas, cuci baju, bersih- bersih rumah......apalagi makan juga cuma sederhana seringkali tidak perlu lauk, asal ada nasi lauknya lapar ......" (Informan Ibu Wasirah)

Ibu Wasirah setiap hari melakukan pekerjaan rumah tangga dan mencari nafkah. Setiap pagi Ibu Wasirah pergi mencari rumput untuk makan ternak yang dipelihara. Pekerjaan rumah tangga yang harus diselesaikan jauh lebih ringan dibanding pekerjaan mencari nafkah. Ibu Suprih memelihara ternak setiap hari harus mencari hijauan makanan ternak. Selain mengelola ternak Ibu Suprih mengelola lahan pertanian dan menyelesaikan pekerjaan rumah tangga sendiri.

Konstruksi sosial budaya telah menempatkan suami tidak harus ikut membantu menyelesaikan pekerjaan rumah tangga. Anak pertama Ibu Wasirah sudah berumah tangga meskipun belum sempat menamatkan pendidikan di SD setempat. Saat ini Ibu Wasirah tinggal bersama anak, menantu, dan cucu. Anak kedua dan ketiga belum berumah tangga. Anak kedua menjadi pembantu di Yogjakarta dan anak ketiga masih sekolah kelas VI SD. Anak- anak Ibu Wasirah sejak masih anak- anak telah dibiasakan membantu pekerjaan orang tua di ladang, memelihara ternak, dan pekerjaan lainnya yang biasa dilakukan Ibu Wasirah. Setelah menyelesaikan sekolah dasar anak-anak Ibu Wasirah ti- 
dak melanjutkan ke jenjang pendidikan lebih tinggi karena kendala biaya.

"......jika tidak memelihara sapi mau apa lagi hidup disini banyak waktu luangnya......setiap hari butuh makan jika tidak bekerja bertambah susah......ternak sapi mendapat pinjaman sekarang punya satu indukyang sudah jadi milik sendiri......saat mempunyai kebutuhan banyak induknya dapat dijual......" (Informan Ibu Wasirah)

Bekerja keras melakukan pekerjaan di lahan pertanian, bekerja di peternakan, dan bekerja dengan memanfaatkan sumber daya sekitar merupakan kegiatan rutin Ibu Wasirah. Sebagaimana dikemukakan Ibu Wasirah mengenai kegiatan yang dilakukan untuk membantu memenuhi kebutuhan rumah tangga. Ibu Suprih kondisinya hampir sama yakni semua pekerjaan rumah tangga, pekerjaan mencari nafkah, kegiatan sosial kemasyarakatan menjadi tanggung jawab Ibu Suprih sebagai kepala rumah tangga.

“......bekerja keras kalau sudah biasa tidak terasa berat......tadi pagi saya sudah mencari rumput dan mengambil salak serta daun pisang .....kemudian dijual untuk memenuhi kebutuhan......kadang anak- anak membantu mencari rumput......penting ternak kenyang dulu..." (Informan Ibu Suprih)

Ibu Suprih bekerja di sawah dan pekarangan untuk memenuhi kebutuhan rumah tangga. Meskipun demikian sebagai perempuan menyelesaikan pekerjaan rumah tangga merupakan tugas utama yang tidak pernah ditinggalkan. Pekerjaan rumah tangga dianggap ringan bagi perempuan miskin yang selalu melakukan pekerjaan berat ikut mencari nafkah.

Keterbatasan kesempatan memperoleh pendidikan karena ketiadaan biaya, jauh dari fasilitas pendidikan menjadikan perempuan miskin memiliki pendidikan rendah bahkan dari ketiga informan tidak sempat menyelesaikan bangku sekolah dasar. Pendidikan perempuan kepala rumah tangga relatif rendah sebagaimana Ibu Wasirah dan Ibu Hardiyati pernah memperoleh pendidikan di sekolah dasar meskipun tidak sempat menyelesaikan pendidikan tersebut karena harus menikah.

“......saya pernah sekolah sampai kelas tiga SD......saya keluar dari sekolah lebih baik membantu orangtua bekerja di ladang...... orangtua nggak ada biaya.......kalau suami saya lulus SD......" (Informan Ibu Suprih)

Sebagaimana Ibu Suprih, tidak dapat menamatkan sekolah sesudah menyelesaikan SMP, berbeda dengan Ibu Hardiyati sempat menyelesaikan SMA meskipun sejak anakanak harus bekerja membantu orang tuan bekerja di sawah dan memelihara ternak. Menurut Ibu Suprih kesulitan ekonomi membuat mereka tidak dapat melanjutkan sekolah. Pendapatan yang diperoleh hanya dapat untuk memenuhi kebutuhan sehari-hari, untuk melanjutkan sekolah diperlukan biaya cukup banyak sehingga memberatkan beban orang tua.

\section{Strategi Bertahan Hidup Rumah Tang- ga Miskin dengan Perempuan Kepala Rumah Tangga}

Pendapatan per kapita per tahun menjadi salah satu indikator untuk menentukan karakteristik rumah tangga miskin. Strata pengelompokan rumah tangga didasarkan atas pendapatan per kapita per rumah tangga. Kelompok rumah tangga miskin apabila pendapatan per kapita per tahun dalam rumah tangga kurang atau sama dengan 240 $\mathrm{kg}$ harga beras setempat dalam setahun. Kelompok rumah tangga tidak miskin apabila pendapatan per kapita per tahun dalam rumah tangga lebih dari $240 \mathrm{~kg}$ harga beras setempat dalam setahun. Mendasarkan harga beras setempat, termasuk dalam kategori rumah tangga miskin apabila mempunyai pendapatan per kapita per tahun kurang atau sama dengan Rp 1.320.000 dan kategori rumah tangga hampir miskin apabila pendapatan per kapita per tahun lebih dari Rp 1.320.000 per kapita pertahun. Asumsi harga beras di daerah penelitian tahun 2011 ketika penelitian dilakukan adalah Rp 5500 per kg. Kegiatan pertanian berperan penting memberi sumbangan pendapatan rumah tangga 
di perdesaan. Perdesaan dengan aksesibilitas baik, dihadapkan dengan bertambahnya jumlah penduduk yang memerlukan perluasan pemukiman, perluasan kegiatan ekonomi, sosial, dan kegiatan lain untuk memenuhi kebutuhan penduduk turut mempengaruhi keberadaan lahan pertanian. Ketersediaan lahan garapan yang semakin terbatas tanpa disertai penerapan teknologi pertanian menyulitkan rumah tangga yang menggantungkan pendapatan dari pertanian, apabila tetap bertahan di pertanian. Modal merupakan kendala untuk mengembangkan berbagai kegiatan ekonomi di perdesaan. Petani dengan lahan garapan sempit, bahkan petani yang tidak memiliki tanah mulai tampak nyata di ketiga dusun penelitian terutama melanda perempuan miskin. Kelompok marginal ini merupakan kelompok yang semakin terpuruk dalam kemiskinan, karena tidak memiliki lahan pertanian sebagai tumpuan utama pendapatan rumah tangga. Keterbatasan sumberdaya menjadi kendala untuk menguasai sumber pendapatan di perdesaan sehingga memaksa mereka tetap bertahan di perdesaan untuk hanya sekedar bertahan hidup dengan bekerja seadanya. Rumah tangga miskin memiliki keterbatasan sumberdaya ekonomi untuk memenuhi kebutuhan hidup. Keterbatasan ekonomi ini sering menjadi kendala bagi rumah tangga miskin dapat lumrah di masyarakat. Keterbatasan ekonomi berkaitan dengan buruknya derajat kesehatan karena pemenuhan kebutuhan pangan dan pemeliharaan kesehatan serta lingkungan yang kurang memadai. Kesulitan ekonomi rumah tangga miskin lebih berat dipikul oleh rumah tangga dengan kepala rumah tangga perempuan.

Upaya rumah miskin dengan kepala rumah tangga perempuan untuk bertahan hidup dapat dilihat dari kehidupan Ibu Suprih. Suami Ibu Suprih telah 12 tahun meninggal sehingga seluruh tugas dan tanggung jawab rumah tangga harus dipikul sendiri Ibu Suprih, apalagi anak- anak waktu itu masih kecil. Ketika masih ada suami sebenarnya rumah tangga Ibu Suprih juga dililit kemiskinan sehingga memaksa Ibu Suprih membantu mencari nafkah dengan bekerja sebagai buruh tani. Kemiskinan tersebut semakin parah karena Ibu Suprih harus bekerja mencari nafkah sendiri ketika anak-anak masih kecil. Beruntung bagi Ibu Suprih, saat ini anaknya pertama dan kedua sudah dapat mencari nafkah, anak pertama membantu di bengkel sepeda motor, anak kedua membantu bekerja di toko mebel, dan anak ketiga Ibu Suprih masih sekolah di SMP swasta. Ibu Suprih saat ini masih tetap bekerja sebagai buruh tani dan membantu memelihara tanaman salak di tempat tetangga. Ibu Suprih memiliki sepetak kebun yang diusahakan untuk tanaman salak pondoh. Pendapatan yang diperoleh dari tanaman salak di kebun seluas 500 meter peninggalan dari orang tua Ibu Suprih tidak mampu untuk memenuhi kebutuhan hidup sehari- hari.

".....kebutuhan sehari- hari terutama untuk makan masih dapat dipenuhi seadanya dari pendapatan usahataninya serta bekerja sebagai buruh tani dan membantu tetangga.... tetapi kebutuhan sosial justru lebih berat.....agar dapat lumrah.....untuk nyumbang ketika tetangga dan saudara punya gawe....anak saya yang masih sekolah belum banyak memerlukan biaya..... kecuali dulu ketika kakaknya sekolah di SMK sangat berat bagi saya untuk menyediakan biaya sekolah.....sekarang dia sudah bekerja..... meskipun gajinya hanya cukup untuk kebutuhan mereka......." (informan Ibu Suprih)

Pada saat anak- anak masih sekolah di SMK, Ibu Suprih terpaksa mencari pinjaman ke tetangga atau sanak famili untuk memenuhi kebutuhan rumah tangga. Beban sosial yang harus ditanggung Ibu Suprih saat itu lebih berat karena mencari pinjaman bukan pekerjaan yang mudah bagi perempuan miskin. Ibu Suprih hanya dapat memperoleh pinjaman dari orang yang benar-benar percaya kepada Ibu Suprih. Kesulitan memenuhi kebutuhan hidup sehari- hari karena pendapatan yang diperoleh sangat kecil menjadikan Ibu Suprih kesulitan mengembalikan pinjaman. Ibu Suprih memperoleh pinjaman dari tetangga tempat Ibu Suprih bekerja membantu sebagai buruh tani atau 
membantu pekerjaan lainnya di rumah. Pinjaman uang sering tidak dapat dikembalikan dengan uang oleh Ibu Suprih, Ibu Suprih mengembalikan pinjaman dengan membantu bekerja di lahan usahataninya dan bekerja membantu menyelesaikan pekerjaan rumah tangga pemberi pinjaman.

“.....ketika membantu pekerjaan tetangga saya dapat jatah makan.....makanan saya bawa pulang agar anak saya dapat makan tanpa saya harus memasak....semakin sering saya diminta membantu pekerjaan berarti kebutuhan makan untuk anakanak pada hari itu dapat terpenuhi dari jatah makan saya.....saya tidak sempat memikirkan untuk makan sendiri.... yang penting anak- anak tidak kelaparan....." (informan Ibu Suprih)

Mengurangi jatah makan dan mengurangi konsumsi makanan merupakan strategi bertahan hidup yang dilakukan rumah tangga miskin dengan kepala rumah tangga perempuan. Jatah makan dan konsumsi dikurangi seringkali belum cukup membantu rumah tangga dengan kepala rumah tangga perempuan bertahan hidup. Kualitas makan yang telah buruk ditekan lagi sehingga benar-benar buruk sehingga tidak memenuhi standard. Perempuan kepala rumah tangga mengetahui kondisi tersebut secara berkepanjangan akan berdampak pada kekurangan gizi dan menurunkan derajad kesehatan mereka. Namun demikian tetap saja hal tersebut harus dilakukan agar dapat bertahan hidup meskipun dengan kualitas hidup yang semakin buruk.

".....saya sering diminta membantu pekerjaan tetangga....tentu saja dapat jatah makan.....makanan saya bawa pulang untuk anak saya ....semakin sering saya diminta membantu pekerjaan berarti kebutuhan makan hari itu dapat terpenuhi .....apabila makanan yang tersedia hari ini tidak cukup saya harus mengalah untuk anak- anak......lebih baik saya mengalah dengan makan seadanya yang penting ada nasi......dari pada saya harus mencari pinjaman ke warung untuk makan hari ini......" (Informan Ibu Suprih)
Pekerjaan perempuan kepala rumah tangga relatif berat yakni menyelesaikan pekerjaan rumah tangga dan mencari nafkah. Beban berat itu ditambah dengan kondisi perempuan yang selalu mengalah dengan anggota rumah tangga lain dalam pemenuhan pangan. Keadaan ini tentu saja berdampak pada rendahnya derajad kesehatan perempuan kepala rumah tangga. Ketika sakit seringkali hanya dilakukan dengan pengobatan seadanya, bahkan kalau hanya sakit ringan akan dibiarkan agar sembuh sendiri.

\section{SIMPULAN}

Rumah tangga dengan kepala rumah tangga perempuan semakin kesulitan memenuhi kebutuhan ekonomi mereka ketika dihadapkan dengan ketiadaan sumberdaya produktif yang dimiliki. Upaya rumah miskin dengan kepala rumah tangga perempuan dalam mengatasi kesulitan ekonomi yang sering dihadapi antara lain melalui berbagai cara seperti melakukan penganekaragaman usaha ekonomi seperti pemanfaatan sumberdaya yang tersedia di sekitarnya. Menambah pendapatan rumah tangga dilakukan dengan melibatkan seluruh anggota rumah tangga agar memiliki kegiatan yang dapat menghasilkan pendapatan. Kesulitan ekonomi rumah tangga dengan kepala rumah tangga perempuan seringkali diatasi dengan meminjam uang kepada tetangga maupun dari keluarga terdekat. Guna pemenuhan kebutuhan pangan atau kebutuhan mendesak lainnya dilakukan rumah tangga dengan kepala rumah tangga perempuan terlebih dahulu dengan cara mengambil barang kebutuhan di warung-warung terdekat untuk pemenuhan kebutuhan. Menekan kebutuhan rumah tangga serendah mungkin sering dilakukan agar dapat bertahan hidup meskipun mereka mengetahui bahwa dengan kualitas pemenuhan kebutuhan yang minimal seperti kebutuhan pangan, menjadikan mereka rentan terhadap gangguan kesehatan mereka.

\section{UCAPAN TERIMA KASIH}

Kami ucapkan terima kasih kepada para informan yang terlibat dalam penelitian 
ini serta masyarakat Desa Donokerto, Turi, Sleman, Daerah Istimewa Yogyakarta sehingga penelitian ini dapat berjalan dengan baik. Selain itu kami ucapkan terima kasih kepada pihak-pihak yang turut membantu support dana sehingga penelitian ini bisa berjalan dengan lancar. Selanjutnya kami ucapkan terima kasih kepada redaksi yang telah mempublikasikan artikel hasil penelitian ini sehingga penelitian ini dapat dibaca oleh berbagai kalangan. Hasil penelitian ini masih dapat dikembangkan ke dalam bentuk penelitian lain sehingga kami berharap penelitian ini dapat dijadikan sebagai referensi terhadap penelitian selanjutnya. Semoga hasil penelitian ini bermanfaat bagi perkembangan ilmu pengetahuan.

\section{DAFTAR PUSTAKA}

Bungin, Burhan. 2003. Analisis Data Penelitian Kualitatif. Jakarta: PT Raja Grafindo Persada.

Miles, Matthew B \& Michael Huberman. 1992. Analisis Data Kualitatif. Diterjemahkan oleh Tjetjep Rohendi Rohidi. Jakarta : Universitas Indonesia Press.

Sajogyo, 1986. Pembagian Kerja Antara Pria Dan Wanita Di Bidang Pertanian Bogor. Buku kenan kenangan untuk Selo Sumardjan

Stichter, Sharon and Jane, L, Partpart (eds), 1991. Women, Employment and The Family in The International Division of Labour. Philadelphia: Temple University Press

Suratiyah, Ken dan Hariadi, Sunarru Samsi, 1991. Wanita Kerja dan Rumah Tangga: pengaruh Pembangunan Pertanian terhadap Peranan Wanita Perdesaan Di DIY. Yogyakarta: PPK UGM. 